Winter 2015

\title{
The Aspiring and Globalizing Graduate Law Student: A Comment on the Lazarus-Black and Globokar LL.M. Study
}

Jayanth K. Krishnan

Indiana University Maurer School of Law, jkrishna@indiana.edu

Vitor M. Dias

Indiana University Maurer School of Law, vmdias@indiana.edu

Follow this and additional works at: https://www.repository.law.indiana.edu/ijgls

Part of the International Law Commons, Legal Education Commons, and the Legal Profession

Commons

\section{Recommended Citation}

Krishnan, Jayanth K. and Dias, Vitor M. (2015) "The Aspiring and Globalizing Graduate Law Student: A Comment on the Lazarus-Black and Globokar LL.M. Study," Indiana Journal of Global Legal Studies: Vol. 22 : Iss. 1 , Article 4.

Available at: https://www.repository.law.indiana.edu/ijgls/vol22/iss1/4

This Article is brought to you for free and open access by the Law School Journals at Digital Repository @ Maurer Law. It has been accepted for inclusion in Indiana Journal of Global Legal Studies by an authorized editor of Digital Repository@Maurer Law. For more information, please contactrvaughan@indiana.edu.

\section{$\Psi$}

JEROME HALL LAW LIBRARY

INDIANA UNIVERSITY

Maurer School of Law
Blooming ton 


\title{
The Aspiring and Globalizing Graduate Law Student: A Comment on the Lazarus-Black and Globokar LL.M. Study
}

\author{
JAYANTH K. KRISHNAN* \& VITOR M. DIAS ${ }^{\star *}$
}

INTRODUCTION

Mindie Lazarus-Black and Julie Globokar have written a researchrich and interesting study on U.S. LL.M. programs and the students who enter them. Their paper focuses on the dynamics of the application process for entering into an LL.M. program by examining "the perspectives and experiences of the administrators who make admissions decisions and the students who seek admission."1 LazarusBlack and Globokar build on the work of researchers who have been focusing on these and related issues for some time, including Carole Silver, Yves Dezalay, and Bryant Garth, among others. ${ }^{2}$ The authors do an excellent job of rigorously analyzing their core subject and

* Professor of Law, Charles L. Whistler Faculty Fellow, and Director of the Center on the Global Legal Profession, Indiana University Maurer School of Law.

** Research Fellow, Center on the Global Legal Profession and LL.M. Thesis Student, Indiana University Maurer School of Law. Dias is also a licensed lawyer in Brazil.

1. Mindie Lazarus-Black \& Julie Globokar, Foreign Attorneys in U.S. LL.M. Programs: Who's In, Who's Out, and Who They Are, 22 InD. J. Global LeGal STUD. 3, 7 (2015).

2. See generally Carole Silver, The Variable Value of U.S. Legal Education in the Global Legal Services Market, 24 GEo. J. LEGAL ETHICS 1, n.16 (2011); Carole Silver, Internationalizing U.S. Legal Education: A Report on the Education of Transnational Lawyers, 14 CARDOZO J. INT'L \& COMP. L. 143, 146 (2006) [hereinafter Silver, A Report]; Carole Silver, States Side Story: Career Paths of International LL.M. Students, or "I Like to be in America," 80 FORDHAM L. REV. 2383 (2012). See generally YVES DEZALAY \& BRYANT G. GaRTH, THE INTERNATIONALIZATION OF PALACE WARS: LAWYERS, ECONOMISTS, AND THE CONTEST TO TRANSFORM LATIN AMERICAN STATES (2002); Global Prescriptions: The Production, Exportation, and Importation of a New Legal ORThodoXY (Yves Dezalay \& Bryant G. Garth eds., 2005); Yves DEZALAY \& BRYANT G. GaRTH, DEALING IN VIRTUE: INTERNATIONAL COMMERCIAL ARBITRATION AND THE CONSTRUCTION OF A TRANSNATIONAL LEGAL ORDER (1996), for a selection of works cited that are authored or edited by Yves Dezalay and Bryant Garth. See also id. at 6 .

Indiana Journal of Global Legal Studies Vol. 22 \#1 (Winter 2015)

(C) Indiana University Maurer School of Law 
successfully answering the four key questions they set forth in their introduction:

Who gets accepted into LL.M. programs? Who does not? Which types of international, national, and local policies and laws must foreign attorneys navigate if they want to study in the United States? What kinds of political, economic, linguistic, and social capital must they demonstrate to gain admission to law school? ${ }^{3}$

Lazarus-Black and Globokar's methodology is a nice combination of quantitative and qualitative techniques. The ethnographic research they conducted within two law schools (one located in the Midwest and the other on the East Coast) is particularly interesting. This research involved collecting important interview data from professors, administrators, and LL.M. students themselves. The authors' study is a valuable contribution for two important reasons. First, it sheds crucial light on law schools' strategies regarding their foreign graduate law programs. Second, the findings provide a menu of reasons for why foreign applicants wish to pursue an LL.M. degree. There is no doubt that observers who focus on legal education and the legal profession will greatly benefit from Lazarus-Black and Globokar's thoughtful and insightful work.

Given that Lazarus-Black and Globokar's entire article precedes this Comment in this special issue of the Indiana Journal of Global Legal Studies, we will not summarize either their findings or the other detailed sections they provide. (We encourage readers to study these parts with careful attention.) Rather, and most interestingly for us, we plan to examine here a critical point in their work that relates to the complicated and nuanced issue of motivation-namely, the motivation of foreign applicants who wish to come to the United States to study. Before addressing this point, however, it is important to mention that the authors do discuss the motivations of law schools in seeking to attract LL.M. students. Law schools, for example, often embrace students from abroad who can add international diversity (socioeconomically, linguistically, racially, and ethnically). ${ }^{4}$ U.S. law schools are also interested in extending their networks abroad; recruitment of international LL.M. students in places of interest is a

3. Lazarus-Black \& Globokar, supra note 1, at 7.

4. See id. at 28 . 
good way to accomplish this objective. ${ }^{5}$ In addition, LL.M. students bring different perspectives to the classroom and offer important intellectual engagement to faculty, staff, and other students. ${ }^{6}$ And of course, law schools value LL.M. programs for financial support; the tuition paid by foreign LL.M. students is a significant means of revenue for law schools. ${ }^{7}$

In terms of the motivation of LL.M. students-which is our main interest-Lazarus-Black and Globokar rely on existing literature as well as offer their own set of reasons for what motivates this cohort to pursue this degree. As the authors note, motivation varies "by age, previous education, work experience, and, sometimes, the vicissitudes of legal practice in [the students'] home countries." Globokar are able to find several general patterns that emerge despite these differences. To begin, the applicants see the LL.M. degree as offering an opportunity to enhance their professional career possibilities. ${ }^{9}$ Some applicants may aspire to work in the United States; others may have better opportunities upon returning home; and still others may hope to engage in cross-border work in multiple jurisdictions. ${ }^{10}$

Another reason relates to satisfying "personal" situations. ${ }^{11}$ This scenario occurs where applicants-who have had legal training in their respective home jurisdictions-move to the U.S. for spousal or family reasons and are presented with, and seize upon, the opportunity of "practicing their chosen profession in another country." 12 Candidates may also be motivated to enter into an LL.M. program for the sheer intellectual challenge of a U.S. legal education. ${ }^{13}$ Finally, and relatedly, candidates may seek LL.M. degrees because of the belief that they would be exposed to substantive areas of law that either are not present or are doctrinally "underdeveloped" within their own home countries. ${ }^{14}$

5. See id. ("These programs internationalize the student bodies of law schools, which schools use as evidence of their international and even global characters.") (quoting Silver, A Report, supra note 2, at 154).

6. See id. at 56 ("[T]he heterogeneity of the foreign attorneys in terms of countries of origin, age, family, and work experience, as well as their very different social and economic backgrounds, create a diversity in the classroom that is more complicated than ... previously imagined.").

7. Id. at 26 .

8. Id. at 44 .

9. Id. at 45 .

10. Id.

11. Id.

12. Id.

13. Id.

14. Id. 
Lazarus-Black and Globokar's evidence and findings are illuminating and noteworthy. Yet, we are also interested in delving into more detail on this key concept of motivation. The authors give rich examples of how LL.M. applicants are motivated by different factors in making their respective decisions. But we are keen on uncovering a general theory of motivation from their discussion. So, for example, when we are told that applicants desire LL.M. degrees-to learn more about a substantive legal area; to satisfy their intellectual curiosity; to accommodate a personal lifestyle situation; or to achieve a career objective-we would like to consider whether these observations might be made within a broader framework regarding motivation.

Scholars of psychology, organizational behavior, and public policy have long theorized about why people are motivated to engage in certain behaviors over others. ${ }^{15}$ Drawing on this rich literature could have been useful for Lazarus-Black and Globokar: it would have framed their analysis in more general, theoretical terms, which could have then driven the methodology and subsequent empirical findings. Instead, as the article stands now, it states the methods and then describes the findings, with minimal theory on motivation to set the stage.

As a thought experiment, in the next section we present a theoretical frame (that builds on what previous scholars have discussed) for understanding motivation-as it relates to the subject focused on by Lazarus-Black and Globokar. Based on this model, we then postulate an alternative motivation for why foreign applicants might wish to pursue their LL.M. studies. We base our hypothesis on the experiences we have had in two countries we know well: India and Brazil. Because this is just a short Comment, we leave the empirical work on our proposal for future research. Our hope is that this exercise might generate a wider theoretical discussion on a critical subject that deserves further investigation.

15. For a view about the origins of the theory of motivation see SIGMUND FREUD, THE COMPLETE INTRODUCTORY LECTURES ON PSYCHOANALYSIS (James Strachey ed., trans., W.W. Norton \& Company 1966); Clark L. Hull, Essentials of Behavior (1951) [hereinafter HULL, Essentials]; ClARK L. HULL, PRINCIPLES OF BEHAVIOR: AN InTRODUCTION TO BEHAVIOR THEORY (Richard M. Elliot ed., 1943) (hereinafter HULL, Principles]; William James, The Principles of Psychology (Dover Publications 1950) (1890). For a more comprehensive and specific scholarly research on the theory of motivation see Nelson N. Foote, Identification as the Basis for a Theory of Motivation, 16 AM. Soc. REV. 14 (1951); Bernard Weiner, Little-Known Truths, Quirky Anecdotes, Seething Scandals, and Even Some Science in the History of (Primarily Achievement) Motivation, 17 PersonaliTy \& Soc. Psychol. Rev. 293 (2013). 


\section{FRAMING MOTIVATION}

For several decades, researchers have been examining the concept of motivation and trying to explain how it operates and what factors lie behind it. During the first half of the twentieth century, scholars such as William James and Clark Hull studied motivation and concluded that biological and evolutionary forces determined the intensity of drive that individuals possessed. ${ }^{16}$ In 1954, Abraham Maslow, in his classic work Motivation and Personality, ${ }^{17}$ constructed what he saw as a hierarchy of needs that drove individuals to pursue career objectives. ${ }^{18}$ Maslow's hierarchy also stressed an evolutionary vision of the forces behind human motivation. At the bottom of the pyramid were what Maslow called "physiological" needs, with "safety" needs above them, followed by "love and belonging" needs, with an "esteem" need next, and finally a "self-actualization" need at the apex. ${ }^{19}$ Specific examples of human desires could be grouped within each of these broad categories. For example, the need for basic necessities (water, food, air, etc.) was physiological in nature, while wanting to excel at a particular task or objective was viewed as a self-actualization need. ${ }^{20}$ For Maslow, the hierarchy of needs was also sequential; namely, the lower need had to be realized first before progressing to the one above it. ${ }^{21}$

Maslow's work on motivation and needs has been discussed, supported, criticized, and amended by subsequent scholars for over a half century. His research faced particular scrutiny by Herzberg, ${ }^{22}$ Alderfer, ${ }^{23} \mathrm{McClelland},{ }^{24}$ and others. ${ }^{25}$ But in the late $1960 \mathrm{~s}$ and early

16. See HULL, Principles, supra note 15; JAMES, supra note 15; See generally FREUD, supra note 15.

17. See generally Abraham H. Maslow, Motivation and Personality (2d ed. 1970).

18. It is relevant to mention that Maslow's book built off of his famous paper published in 1943. See A. H. Maslow, A Theory of Human Motivation, 50 PSYCHOL. REV. 370 (1943).

19. Id. at $372,376,380-82$.

20. Id. at 372,382 .

21. Id. at 370 .

22. See Frederick Herzberg et AL., The Motivation to Work (2d ed. 1959) (refining Maslow's work by seeing the concept of motivation as being a "satisfier" - or comprising elements such as responsibility, recognition, achievement, and advancement-with dissatisfiers, such as hygiene).

23. See Clayton P. Alderfer, Existence, Relatedness, and Growth: Human NEEDS IN ORGANIZATIONAL SETTINGS (1972) (introducing "ERG Theory," which refers to an individual's motivation for satisfying needs tied to one's existence, relatedness, and growth).

24. See generally David C. McClelland, Toward a Theory of Motive Acquisition, 20 AM. Psychol. 321 (1965) [hereinafter McClelland, Motive Acquisition]; David C. McClelland, Managing Motivation to Expand Human Freedom, 33 AM. PsYCHOL. 201 (1978) (privileging and discussing at length needs such as achievement, affiliation, and power) [hereinafter McClelland, Managing Motivation]. 
1970s, an important contribution by John Bowlby helped transform the way observers conceived of motivation. ${ }^{26}$

An expert on the behavior of children, Bowlby began to reevaluate earlier work on motivational theory and concluded that major gaps existed.27 According to Bowlby, researchers had not paid enough attention to the early ties that children developed with their parents and others close to them. "Attachment theory," as it came to be known, served as the basis for helping to determine emotional maturity, desire, needs, and motivation in later years. ${ }^{28}$ Subsequent empirical work developed to support Bowlby's theory, ${ }^{29}$ and applied it to adults. ${ }^{30}$ Much of this scholarship finds that emotion, feeling, sentiment, and connection to others help define the needs and motivations of an individual; they construct a reality and shape the norms that govern how that individual pursues opportunities. ${ }^{31}$

Considering this above literature in the context under which foreign applicants seek an LL.M. degree, we may be able to explain more broadly why a candidate is driven to acquire this credential. For example, the drive to have an LL.M. as a means of advancing in a career may relate to Maslow's self-actualization point. Or, an applicant may be motivated toward higher education (e.g., an LL.M.) because of a need to

25. See generally Elaine M. Pearson \& Ronald L. Podeschi, Humanism and Individualism: Maslow and His Critics, 50 ADULT EDUC. Q. 41 (1999); EDWARD HofFMAN, THE Right TO BE HuMAN: A BIOGRAPHY OF ABRAHAM MASLOW (1988).

26. See generally volumes I and II of Bowlby's Attachment and Loss, JOHN BOWLBY, ATTACHMENT (1969) [hereinafter BOWLBY, ATTACHMENT]; JOHN BOWLBY, SEPARATION: ANXIETY AND ANGER (1973) [hereinafter BOWLBY, SEPARATION].

27. See generally BOWLBY, ATTACHMENT, supra note 26; BOWLBY, SEPARATION, supra note 26.

28. See generally BowlBy, ATTACHMENT, supra note 26; BOWLBY, SEPARATION, supra note 26; John Bowlby, The Nature of the Child's Tie to His Mother, 39 INT'L J. PSYCHOANALYSIS 350 (1958).

29. See, e.g., Phillip R. Shaver \& Mario Mikulincer, Attachment Theory: I. Motivational, Individual-Differences and Structural Aspects, in THE CAMBRIDGE HandBooK of Personality Psychology 228 (Philip J. Corr \& Gerald Matthews eds., 2009).

30. See id. at 230-232 (citing several works that build on Bowlby that rely on empirical findings to support his theory and its specific application to adults); MARY D. SALTER Ainsworth et al., Patterns of ATtachment: A Psychological Study of the Strange SITUATION (1978) (analyzing the attachment patterns in order to verify a child's quality of attachment to the parents and vice-versa, which can be used to assess the memories of an adult); Mary D. Salter Ainsworth, Attachments and Other Affectional Bonds Across the Life Cycle, in ATtaChment ACRoss THe Life CyCle 33 (Colin Murray Parkes et al. eds., 1991); Phillip R. Shaver et al., The Adult Attachment Interview and Self-Reports of Romantic Attachment: Associations Across Domains and Methods, 7 PERS. RELATIONSHIPS 25 (2000).

31. See generally AINSWORTH ET AL., supra note 30; Ainsworth, supra note 30; Shaver \& Mikulincer, supra note 29; Shaver et al., supra note 30. 
satisfy an ambition for achievement that developed during one's formative years. ${ }^{32}$ Or yet still, an individual's motivation for pursuing an LL.M., for the purposes, say, of meeting a desire to learn about social justice, may trace back to an attachment to caregivers who-while the applicant was young-privileged and promoted values such as compassion, empathy, and equality.

As a way of stimulating this thought experiment, we offer the beginnings of a generalizable framework of our own. We theorize that foreign candidates may seek an LL.M. from a U.S. law school for another reason unexplored by Lazarus-Black and Globokar. In several of the LL.M. students' home countries, the system of legal education is in crisis. ${ }^{33}$ Many law schools in these countries have infrastructural challenges. Pedagogically, teachers instruct their classes using outdated methods and have little incentive or ambition to improve-if they even bother to appear regularly in class at all; research and writing are aspects of the educational enterprise that are left unsupported. Sadly, an academic, scholarly milieu simply does not exist within the legal education space. Because there is this unmet need within their own environments, individuals are motivated to look abroad to obtain selfactualization and maximize their intellectual potential.

We hasten to mention that our point here is distinct from the one made by Lazarus-Black and Globokar when they talk about their subjects' motivations to come to the United States "to pursue intellectual interests." 34 To be sure, they do mention how their respondents "attribute their desire to attain a Western legal education to the fact that their own systems are unequipped to properly prepare them on this trek to attain a just legal system." 35 They, however, do not elaborate on what "their own systems" are. Are they the law schools in the home country? Are they referring to the judicial institutions, the courts, or the overall rule of law? Lazarus-Black and Globokar also

32. See Bowlby, AtTACHMENT, supra note 26; Bowlby, SEPARATION, supra note 26; McClelland, Motive Acquisition, supra note 24; McClelland, Managing Motivation, supra note 24.

33. See Jayanth K. Krishnan, Professor Kingsfield Goes to Delhi: American Academics, the Ford Foundation, and the Development of Legal Education in India, 46 AM. J. LEGAL HIST. 447, 487-97 (2004) [hereinafter Krishnan, Professor Kingsfield]; David M. Trubek, Reforming Legal Education in Brazil: From the Ceped Experiment to the Law Schools at the Getulio Vargas Foundation, in LEGAL STUDIEs RESEARCH PAPER SERIES No. 1180, 8 (2011) (discussing the challenges of legal education in Brazil in a historical perspective); José Eduardo Faria, A Reforma Do Ensino Jurídico [The Reform of Legal Education], 21 REvista CRITICA CIÊNCIAS SOCIAIS 45 (1987) (Braz.) (discussing the legal education system in Brazil and its problems).

34. See Lazarus-Black \& Globokar, supra note 1 , at 45.

35. Id. at 38 . 
discuss how applicants are motivated toward LL.M. programs because of the "theory of lack"-or how "the United States is more 'legally developed' than their home nation in certain areas of law ... [such as] intellectual property, human rights, and immigration . . .."36 But the authors neither directly nor fully discuss another aspect that is glaringly lacking, and one that we see as a primary variable in this discussion: the absence of quality legal education within the countries from where LL.M. candidates come. For us, this point is crucial to understanding why applicants are motivated to leave their home countries and study in the United States. ${ }^{37}$

\section{BRIEFLy CONSIDERING Two CASE STUdIES TOGETHER: A SHORT SET OF HYPOTHESES}

Our above theory might be tested through an analysis of the state of legal education in two countries: India and Brazil. Both countries have important similarities and differences that allow for a methodologically useful comparison. In both India and Brazil, there are over 1,000 law schools. In both countries, the legal markets are thought to be thriving. ${ }^{38}$ One main reason for this conclusion stems from changes in the Indian and Brazilian governments' respective macroeconomic policies dating back to the early $1990 \mathrm{~s}^{39}$ However, this perception is also based on the relatively recent influx of bright and talented lawyers

36. Id. at 37 .

37. At times, Lazarus-Black and Globokar seem to imply that the intellectual aspirations of the applicants are best satisfied by coming to the United States. But they never explicitly explore whether this ambition is tied to a feeling that legal education in the students' home country is inadequate. In fact, it appears quite the opposite when the authors state that many of their subjects are "gifted and . . . 'selected' over the course of their lives into some of the finest schools and universities in their countries of origin ...." Id. at 45 .

38. See Jayanth K. Krishnan, Globetrotting Law Firms, 23 GEO. J. LEGAL ETHICS 57, 64 (2010) [hereinafter Krishnan, Globetrotting]; See generally Fabiano Engelmann, Globalização e Poder de Estado: Circulação Internacional de Elites e Hierarquias do Campo Juridico Brasileiro [Globalization and State Power: International Movement of Elites and Hierarchies of the Brazilian Legal Field], 55 REVISTA DE CIÊNCLAS SOCIAIS 487 (2012) (Braz.) (analyzing legal careers to better understand state power); Jayanth K. Krishnan, Peel-Off Lawyers: Legal Professionals in India's Corporate Law Firm Sector, 9 Socio-Legal REV. 1 (2013) (arguing that Indian lawyers have new opportunities to establish new law firms because of a more liberal, globalized economy) (hereinafter Krishnan, Peel-Off Lawyers]; Trubek, supra note 33 (claiming that democratization, liberalization, privatization, and globalization have created a new Brazil, which requires sophisticated legal services).

39. See Engelmann, supra note 38; Krishnan, Globetrotting, supra note 38; Krishnan, Peel-off Lawyers, supra note 38. 
entering into the profession, notably those who are graduates from each country's few dozen or so well-reputed law schools.

In India, for example, much attention has been paid to a set of "National Law Schools," (NLS), the first of which admitted its first class to start in 1987.40 The conventional wisdom is that these NLS graduates are helping to change the face of the Indian legal profession. Indeed, data show that many NLS alums have proceeded to work in top Indian firms, in Indian corporate counsel offices, in legal academia, in leadership positions in nongovernmental organizations, and in the courtroom as successful litigators. ${ }^{41}$

However, what is omitted from the discussion far too often is the fact that these highly reputed NLS institutions only comprise a sliver of law schools in India. Although no reliably complete account of the number of actual law schools in the country exists, estimates range between 1,000 and $1,200,42$ with great disparity in the quality of education dispensed. Law schools in India roughly can be categorized into the following groups:

1. The National Law Schools (which are public)

2. The historically reputed public law schools based in Delhi, Chennai, Mumbai, and Kolkata

3. Another set of about twenty to thirty "decently reputed" public institutions that are not in the previous two categories

4. Recently emerging private law schools (where there is variation here too)

5. Several hundred regional law schools, on which little information is known or available

40. See Krishnan, Professor Kingsfield, supra note 33.

41. Id.; See also Krishnan, Globetrotting, supra note 38; Krishnan, Peel-Off Lawyers, supra note 38.

42. See Kian Ganz, Interview: BCI Chief Subramanium Plans to Consolidate 700+ Law Schools, Overhaul Ethics as Part of 30-year-old Reform Dream, LEGALLY INDIA (Jul. 13, 2010, 5:42 PM), http://www.legallyindia.com/201007131090/Interviews/bci-chiefsubramanium-plans-to-consolidate-700-law-schools-overhaul-ethics-as-part-of-30-year-oldreform-dream. 
In Brazil, the situation is analogous, albeit with some differences. According to recent data, there are 1,155 law schools in Brazil,43 although only a small number (of which most are public) are highly regarded and have a national reputation. ${ }^{44}$ Next follows a group of regional law schools that are moderately-to-well reputed, most of which are also public. However, in comparison to Indian law schools, which are mostly public, the vast majority of Brazilian law schools are private, with the quality and reputation varying accordingly. ${ }^{45}$ For example, some, such as the law schools at Fundação Getulio Vargas and Pontifical Catholic University, are among the elite in the country; others, however, are viewed as average; and many others are thought of as poor in the delivery of legal education to students. 46

Based on our own previous research on legal education in India and Brazil, we feel confident making the following observations: in the vast majority of law schools within both countries, the state of legal education is weak. Basic necessities are lacking. In India, electricity, functioning washrooms, and clean water are routinely absent; in Brazil, campus safety is a significant concern. ${ }^{47}$ Furthermore, in most law schools in both countries, library resources are out-of-date, no regular and reliable internet connection exists, and housing facilities for

43. See José Garcez Ghirardi et al., Observatório do Ensino do Direito [Observatory of

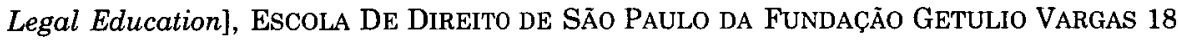
(Oct., 2013) (Braz.), http://direitosp.fgv.br/sites/direitosp.fgv.br/files/arquivos/ anexos/oed__relatorio_01_-_quem_e_o_professor_de_direito_no_brasil.pdf (organizing a database of law schools and law faculty in Brazil). It should be noted that a Brazilian law school based in one city may have a campus in another, from which a student can earn a law degree. Brazilian legal educators would see this situation as there being two separate law schools.

44. See Trubek, supra note 33, at 9.

45. Id. See also Ghirardi et al., supra note 43 , at 18.

46. See Trubek, supra note 33, at 9. See generally JosÉ EdUARDo FARIA, Direitos Humanos, Direitos Sociais E Justiça [Human Rights, Social Rights, and Justice] (2002) (Braz.) (examining the inequality and fragmented nature of many legal institutions including law schools in Brazil); Faria, supra note 33; Luciana Gross Cunha et al., Sociedades de Advogados e Tendências Profissionais [Law Firms and Professional Trends], 3 REVISTA DIREITO GV 6111 (2007) (Braz.) (discussing legal education and emerging tendencies in legal practices in Brazil); Frederico Normanha Ribeiro de Almeida, A Nobreza Togada: As Elites Jurídicas e a Política da Justiça no Brasil [The Togada Nobility: Legal Elites and Justice Policy in Brazil] (2010) ( $\mathrm{PhD}$ dissertation, Universidade de São Paulo) (on file with authors) (discussing the hierarchy of law schools in Brazil).

47. See, Krishnan, Professor Kingsfield, supra note 33, at 466; Tiago Miranda, Proposta Cria Polícia Universitária Federal [Proposal Creates Federal University Police], CÁmara DOS DEPUTADOS (July 15, 2011, 9:28 AM), http://www2.camara.leg.br/camaranoticias/ noticias/EDUCACAO-E-CULTURA/200100-PROPOSTA-CRIA-POLICIA-

UNIVERSITARIA-FEDERAL.html (last visited Sept. 5, 2014) (presenting the terms of a bill proposed to create the federal university police that shall work ensuring the safety of federal universities' campuses). 
students are inadequate. In addition, the teaching of students is often done by part-time faculty who rush from their day jobs to attend classes. ${ }^{48}$ Teaching preparation is not privileged, classes are regularly cancelled, and rote lecturing is the dominant method of instruction. ${ }^{49}$ And most faculty members at the vast majority of law schools in each country simply do not conduct research and clinical work. ${ }^{50}$ In sum, the culture of a learned environment is simply missing.

In fact, even within the comparatively small number of law schools that are viewed as strong, the common belief exists that these institutions have difficulty providing the rigor for which many students are hoping. ${ }^{51}$ In other words, a ceiling deters aspiring students who want more to their education than the first law degree. They look around their environment, and if they happen to attend a law school that is considered to be at the higher end of the "quality spectrum," they are disheartened because they know that they have reached the top academic options available to them. ${ }^{52}$

Given this reality, we would purport to test the following specific hypotheses to evaluate the more general theory set forth above:

Hypothesis 1: We would predict that students with ambitions to learn and to have a positive legal educational experience, who are enrolled in lowerreputed law schools, would be frustrated academically.

Hypothesis 2: We would predict that students with ambitions to learn, to have a positive legal educational experience, and to pursue further graduate legal education, who are enrolled in lower-to-moderately reputed law schools, would see few opportunities (within India or Brazil) to satisfy their motivational need.

Hypothesis 3: We would predict that students mentioned in Hypothesis 2 would wish to enter a program abroad

48. In Brazil, for example, $62 \%$ of law faculty are working under a part-time regime. See Ghirardi et al., supra note 43 , at 79.

49. See Krishnan, Professor Kingsfield, supra note 33; Trubek, supra note 33.

50. See Krishnan, Professor Kingsfield, supra note 33; Trubek, supra note 33.

51. See Krishnan, Professor Kingsfield, supra note 33; Trubek, supra note 33.

52. See Swethaa Ballakrishnen, Homeward Bound: What Does a Global Legal Education Offer the Indian Returnees, 80 FORDHAM L. REV. 2441, 2463-68 (2012); Kian Ganz, Mint Careers Counsel: Should I do an LLM Abroad? Ponderings on India's Fascination with the LLM, LEGALLY INDIA (Jan. 19, 2012, 9:33 PM), http://www. legallyindia.com/201201192507/Careers-Counsel/mint-careers-counsel-should-i-do-an-llmabroad-ponderings-on-indias-fascination-with-the-llm. 
(such as an LL.M. program in the United States) but would perceive themselves as academically unequipped to compete for admission. We would predict their motivational need would go unsatisfied.

Hypothesis 4: We would predict that students with ambitions to learn, to have a positive legal educational experience, and to pursue further graduate legal education, who are enrolled in highly reputed law schools, would wish to enter a program abroad such as an LL.M. program in the United States. We would predict that Lazarus-Black and Globokar's story of Asmar would be confirmed, specifically as it relates to their citation of Mattei and Nader's "theory of lack." 53 But we would predict that in addition to craving intellectual rigor for its own sake, such as gaining substantive knowledge in a particular legal area, a corresponding motivation for entering a program abroad would be related to the frustration over the lack of such educational opportunities in law schools within the home country. ${ }^{54}$

Indeed, we could envision an interesting study taking place between India and Brazil. Namely, fieldwork could be conducted to identify the number of law schools within each country that have graduate-level law programs. From there, samples from each of the five categories of schools we listed in each country would be examined with a focus on several variables, including: the location where LL.B. graduates and, if present, their LL.M. counterparts typically work after matriculation; 55

53. See Lazarus-Black \& Globokar, supra note 1 , at 37.

54. For one scholar who has expressed such frustration, see C. Raj Kumar, Legal Education, Globalization, and Institutional Excellence: Challenges for the Rule of Law and Access to Justice in India, 20 IND. J. GLOBAL L. STUD. 221, 231 (2013), noting that despite this frustration, there has been some improvement in Indian legal education, with, for example, the NLSs and other reforms and initiatives that have been undertaken. See also Ballakrishnen, supra note 52, at 2467-68 (analyzing the role of how the NLSs helped change the process and substance of Indians seeking an LL.M. degree); Krishnan, Professor Kingsfield, supra note 33, at 473-75; Jayanth K. Krishnan, From the ALI to the ILI: The Efforts to Export an American Legal Institution, 38 VAND. J. TRANSNAT'L L. 1255, 1279-88 (2005). As for the Brazilian perspective, see generally Engelmann, supra note 38, discussing how the globalization of the legal profession has affected the Brazilian market with regard to the increase in the number of legal professionals who seek international legal education.

55. Note, in Brazil, the graduate law degree after the LL.B. is commonly referred to as an "Academic Masters," although some other options for graduate studies are available. 
the importance of kinship and existing familial relationships with respect to where graduates practice; ${ }^{56}$ the gender breakdown of students in each category of schools; the career trajectories of students who opt not to practice law; and-most relevant to the Lazarus-Black and Globokar study-the number of students interested in pursuing graduate legal education either in their home country or abroad.

\section{CONCLUSION}

In sum, we are grateful for the opportunity to review Lazarus-Black and Globokar's work. As we stated at the outset, we believe their study is important and makes a significant contribution to the literature. Our Comment here is not meant to impugn their efforts in any way. We simply seek to build on their work and to provide a wider theoretical framework for understanding what motivates foreign applicants to make the choices they do, as these choices relate to pursuing graduate legal work in the United States. We recognize, as we mentioned earlier, law schools also have their own motivations for enrolling foreign students into LL.M. programs. This aspect of the equation could surely be more broadly theorized as well-particularly as higher education institutions in general are operating in this era of globalization-but we leave that issue for another day. For now, our hope is that future researchers may further this discussion and conduct additional empirical research to expand on the authors' terrific study and perhaps to test our theory and hypotheses as well.

\footnotetext{
For purposes here, though, (and actually when Brazilians translate the term for American audiences), the Academic Masters degree is often referred to as an LL.M.

56. See generally Ballakrishnen, supra note 52 (discussing factors motivating the return of Indian students after completing legal education abroad and the role of kinship in Indian legal practice); Krishnan, Peel-Off Lawyers, supra note 38 (discussing the impact of family relationships and kinship on career advancement in Indian law firms).
} 